\title{
Technical and Scale Efficiency Analysis of 25 Nort Mediterranean Ports: A Data Envelopment Analysis Approach
}

\author{
Buljan Perusic Nikolina ${ }^{1} \&$ Zhang Jian Hua ${ }^{1}$ \\ ${ }^{1}$ School of Economics, Huazhong University of Science and Technology, Wuhan, P.R. China \\ Correspondence: Buljan Perusic Nikolina, School of Economics, Huazhong University of Science and \\ Technology, Wuhan. P.R. China. Tel: 086-188-2736-8142. E-mail: nikolina.buljan@yahoo.com
}

Received: December 26, 2019

Accepted: February 20, $2020 \quad$ Online Published: February 22, 2020

doi:10.5539/ijef.v12n3p55

URL: https://doi.org/10.5539/ijef.v12n3p55

\begin{abstract}
The strategic position of the northern Mediterranean ports gained importance with the announcement of Chinese investments, which form part of the One Belt One Road project. The research presented in this paper focuses on small ports, which have not heretofore been the subject of interest. In the first half of 2019, both Croatia and Italy agreed on participation in the project, which aims to shorten the journey from China to central Europe by changing sea route destinations to ports in the Adriatic Sea. This paper examines the technical and scale efficiency of 25 ports in Croatia, Italy and Slovenia, as a possible prerequisite for investments. The research uses Data Envelopment Analysis (DEA) variable returns to scale an output-oriented model on a panel data sheet, for 25 ports in the period from 2009 to 2018. This research suggests that the number of efficient ports, in this case, is not directly related to the size of the port or to the country in which it is located. However, it is more often the case that larger ports are more efficient. For all inefficient ports, the DEA provides best practice examples to which ports should aspire and therefore highlights the practical implication of the work.
\end{abstract}

Keywords: technical efficiency, scale efficiency, cargo ports, DEA, output-oriented

\section{Introduction}

Some of the ports that are the focus of this research could be those considered for investments by the Twenty-First Century Maritime Silk Road project, which is part of the One Belt One Road (OBOR) initiative presented by Chinese president Xi Jinping in 2013. The journey from Shanghai to the northern Adriatic Sea is approximately 8,600 miles, compared to 11,000 miles from Shanghai to Hamburg. The latter route requires an additional eight days of navigation (Putten, Seaman, Huotari, Ekman, \& Otero-Iglesias, 2016). Thus, the Adriatic Sea is the fastest maritime route from China to central and northern Europe, which places additional importance on the strategic position of ports in the Adriatic Sea. Once ships arrive at Adriatic ports, the goods they carry can be transported to other European countries by railway. This requires considerable changes to the infrastructure of both ports and railways. The Italian ports of Venice and Trieste are already trying to be more competitive in these fields, in order to meet the needs of OBOR. The port of Venice is planning to build a new offshore port that can accommodate vessels of up to 18,000 TEU, while the Port of Trieste is investing in a new railway facility that will facilitate transporting goods from Italy to Europe and that will be able to manage 2 million TEU (Fardella \& Prodi, 2017). The authors of The Political Economics of the New Silk Road assert that trade through railroads between east Asia and Europe only accounts for around three percent of the total trade between these continents. In comparison, sea routes currently manage around 95 percent of trade. In addition, in terms of costs, shipping goods by sea is much more affordable than transporting goods by land routes (Sárvári \& Szeidovitz, 2016). Thus, ships docking in the Adriatic Sea, instead of taking more roundabout routes, would markedly reduce costs.

This research evaluates the effectiveness of these ports, including examining key investment factors, the depth of the channels, anchorage depth, import volume, availability of the railway, and nearest airport distance. All these factors are included under the assumption of their importance for a well-functioning delivery channel, from transporting goods by ship to delivering goods to destination countries by other means of transport. Seaport performance can be measured by evaluating productivity or efficiency. Productivity evaluation considers infrastructure outputs, while efficiency measures the highest possible potential output that can be produced with given inputs (Baran \& Gorecka, 2015). The two most commonly used techniques for efficiency evaluation are Stochastic Frontier Analysis (SFA) and DEA. Previous SFA research on technical efficiency concluded that most 
ports have responded positively to the hypothesis that imports affect ports' competitiveness and efficiency, since ports are aware of trade impact when making infrastructure changes. Tests of several model variations revealed that the best technical efficiency was achieved by the model in which imports were in the deterministic part (Buljan Perusic \& Zhang, 2019). This research present analysis of inefficient ports, through separate technical efficiency and scale efficiency evaluations that use DEA analysis with output orientation. To our knowledge, this type of research has not been performed on the mentioned cargo ports. The results on inefficient ports could be useful for port management, to determine the source of the inefficiency and to address their reference ports. For port decision-makers and managers, it is more convenient to influence output level to achieve full technical efficiency than to intervene in infrastructural changes of inputs over a short period of time. DEA analysis is suitable for this research because it returns efficiency scores and indicates in which areas inefficient ports need to improve, in order to operate at a higher level.

\section{Literature Review}

Data envelopment analysis (DEA) is a non-parametric linear program, which is used to estimate different kinds of efficiency. This technique differs from other efficiency analysis, as DEA observes single units and compares them to others, rather than finding averages of all units. A single unit in DEA is named a decision-making units (DMUs), which, in our case, is each port. The usual process of research is to find the most efficient DMUs, which are then compared to others. To calculate relative efficiency, the model needs to run $n$ times for each DMU (Toloo \& Nalchigar, 2009). All observations are 'enveloped' and from there are selected 'frontiers' ones. (Cooper, Seiford, \& Tone, 2006). This analysis calculates the amount of inefficiency for every unit, according to the best DMU, and puts others on the efficiency frontier or under it. In our research, each port is represented as a single DMU. This technique was introduced in the late 1970s, and, since then, it has been constantly upgraded and disseminated throughout a range of industries studies, due to its ability to handle multiple inputs and outputs and to calculate technical, scale, allocative, and other types of efficiency. In 1957, Farell warned researchers that it is inadequate to interpret efficiency on the basis of one input, as this fails to include multiple inputs. His proposed technique thus covers multiple inputs with only one output (Farrell, 1957). Later, in 1978, the DEA technique was introduced with an extension named CCR, which is based on a set of described foundations but also includes multiple input and multiple output solutions that measure efficiency and input orientation (Charnes, Cooper, \& Rhodes, 1978). The technique measures DMUs, using a constant return to scale (crs), meaning that all DMUs should obtain their optimal scale. Later, a variable returns to scale (vrs) model version of DEA was introduced, which allows differentiation between pure technical and scale efficiency (Banker, Charnes, \& Cooper, 1984). This model is named BCCthe after the surnames of the authors that proposed it.

We use both model versions, BCC and CCR, as both are widely used and applied in the evaluation of healthcare institutions, education systems, state institutions, and numerous industries. Togzon (2001) was the first to apply DEA to ports, in a study based on the earlier approach of Roll and Hayuth (1993). Where data in this latter study was hypothetical, Togzon applied the proposed approach to real data measuring selected Australian ports' technical efficiency. He stated that the DEA technique has multiple benefits regarding measuring port efficiency. Firstly, DEA is able to handle multiple outputs, as opposed to conventional estimation methods that are only able to incorporate one output. Togzon use two different outputs, as well as throughput and ship working rate. Secondly, DEA focuses on individual observations, which is not the case in other statistical approaches that focus on calculating averages (Togzon, 2001). In the same year, Valentine and Gray (2001) conducted cross-sectional data research on 31 selected ports, of the world's 100 largest. Their goal was to establish the relationship between ports' efficiency and type of ownership, or the structure of the organisation that manages the port. They used the CCR model of DEA, with two inputs (the total length of berths and length of container berth) and two outputs (total throughput and number of containers). The orientation of the model also plays a major role in the results' outcome. Researchers that use DEA for port efficiency analysis use both an input-oriented model (Kammoun, 2018) and an output-oriented model (Kalgora, Goli, Damigou, Abdoulkarim, \& Amponsem, 2019; Cullinane, Ji, \& Wang, 2005). The applicability of the technique in ports has gained new prominence with the increasingly popular topic of environmental efficiency of ports. Although DEA generally results in high-efficiency values for operational efficiency, the average score is much lower for environmental efficiency. In research on Korean ports, the average DEA result was 0.364 (Chang, 2013). Increasing operational efficiency by investing in equipment and enlarging the number of berths would reduce the consumption of energy and, by that, increase environmental efficiency (Wilmsmeier \& Spengler, 2016).

However, there are several disadvantages to the DEA method for estimating efficiency. Most ports that prove to be inefficient cannot be classified. For example, if both ports are inefficient with values of an 0.80 and 0.8 increase, it cannot be said which port is more efficient (Lee, Chou, \& Kuo, 2005). Additionally, final results are 
very responsive and sensitive to the selection of outputs and inputs, so their choice needs to be analyzed before the final implementation of research. Even then, researchers can not test the appropriateness of the inputs and outputs (Berg, 2010). Nevertheless, because of the amount of detail in the results that are useful for analyzing inefficient ports, this technique is preferred over others. Inefficient seaports lead to higher handling costs, which are a component of total shipping costs. Ports with the lowest charging prices for handling goods are usually those the most efficient ports (Clark, Dollar, \& Micco, 2004).

\section{Model and Data Description}

When time is not taken into consideration, the outcome results of ports' efficiency can be biased, particularly since efficiency can fluctuate over time (Cullinane, Song, Ji, \& Wang, 2004). Therefore, it is desirable to use panel data instead of cross-sectional datasets. Consequently, we track changes over a ten-year period from 2009 to 2018.

We used a DEA command that was established for Stata programming (Ji \& Lee, 2010), which is as follows:

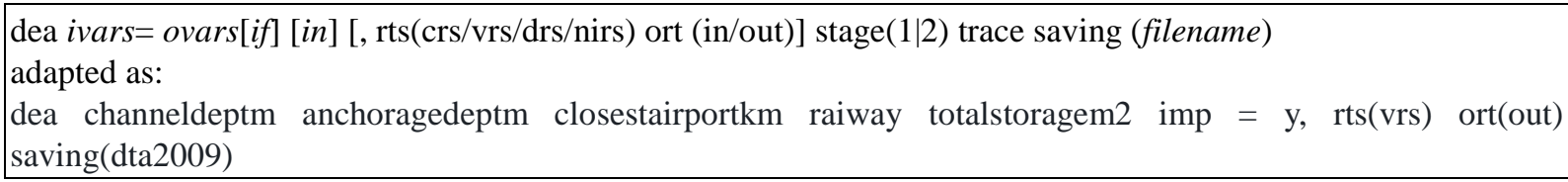

This command makes it difficult for the author to apply key functions and implement inputs or outputs, which the model specifies with ovars [if] [in]. The mentioned function is able to cover multiple inputs and outputs. In our case, we have several inputs, including channel dept, anchorage dept, total storage space, import amount, closest railway and closest airport, as well as one output, which is total ports throughput in thousands of tons. The returns to scale specification $r t s(\mathrm{crs} / \mathrm{vrs} / \mathrm{drs} /$ nirs) gives the option to choose constant returns to scale (crs) as the default option, or variable returns to scale $(v r s)$, decreasing returns to scale $(d r s)$, and nonincreasing returns to scale (nirs). The constant return to scale assumption is used when companies operate on an optimal scale. If this is not the case, due to imperfect competition, different regulations, government intervention, or constrains on finance, some companies might not be able to operate at an optimal scale (Coelli, Rao, O'Donnell, \& Battese, 2005). Examining port efficiency reveals that variable return to scale is a more appropriate election. We use the vrs option, as this includes additional information in the results, in terms of the description of the vrs frontier, which demonstrates that DMUs with a result of 1 are increasing returns to scale (irs) and DMUs with a result of -1 are decreasing returns to scale $(d r s)$. The specification of efficiency orientation can be input-oriented or output-oriented: ort (in/out). The output-oriented model can be justified in the port's industry, through the logic that the port authority can influence production level or output by applying different policies and managerial strategies. However, it is difficult to change inputs by intervening in infrastructure over a short period of time (Liu, 2010). To summarise, it is easier to maximise output, in order to satisfy the level of given input, than to change the input by itself. Stage(1|2) signifies the means of identifying the result slacks. We use the default stage(2) file.

The theoretical background behind the Constat returns to scale (CRS) output-oriented model (CCR model), as interpreted by Huguenin (2012), is as follows:

Maximise $\phi_{k}$

Subject to

$$
\begin{gathered}
\phi_{k} y_{r k}-\sum_{j=1}^{n} \lambda_{j} y_{r j} \leq 0 r=1, \ldots \ldots, s \\
x_{i k}-\sum_{j=1}^{n} \lambda_{j} x_{i j} \geq 0 i=1, \ldots \ldots, m \\
\lambda_{j} \geq 0 \quad \forall_{j}=1, \ldots \ldots, n
\end{gathered}
$$

Where: $\phi_{k}$ represents the efficiency of each unit (DMU);

$\lambda_{j}$ is weights' value for inputs and output of unit $j$;

$\mathrm{y}_{\mathrm{rk}}$ represents the quantity of output $r$ produced by unit (DMU) $k$;

$\mathrm{x}_{\mathrm{ik}}$ quantity of input $i$ that is consumed by unit $k$;

$u_{r}$ is the weight of output $r$;

$v_{i}$ is the weight of input $i$;

$\mathrm{n}$ is the number of units to be evaluated;

$s$ is the number of outputs; 
$m$ is the number of inputs.

Clear specification of the industry's inputs and outputs that are used in this research can determine what orientation to use. It is not best practice to use input-oriented constant returns to scale model in the firms where management is not controlling inputs (D. Cook, Tone, \& Zhu, 2014). In order to decide whether research is valuable, in terms of the proportion of inputs and outputs, and considering the size of a dataset, it is suggested that the number of DMUs should be two or even three times bigger than the combined number of inputs and outputs (D. Cook, Tone, \& Zhu, 2014). Bigger datasets and larger samples are more likely to be more robust, consistent, and less sensitive to change, even if cross-sectional data is observed (Cullinane \& Wang, 2006).

To compare with a VRS output-oriented model (BCC model), $\sum_{j=1}^{n} \lambda_{j}=1$ is added as a measure of returns to scale for unit $k$. (Huguenin, 2012)

Maximise $\phi_{k}$

Subject to

$$
\begin{gathered}
\phi_{k} y_{r k}-\sum_{j=1}^{n} \lambda_{j} y_{r j} \leq 0 r=1, \ldots \ldots, s \\
x_{i k}-\sum_{j=1}^{n} \lambda_{j} x_{i j} \geq 0 i=1, \ldots \ldots, m \\
\sum_{j=1}^{n} \lambda_{j}=1 \\
\lambda_{j} \geq 0 \quad \forall_{j}=1, \ldots \ldots, n
\end{gathered}
$$

The VRS output-oriented model dual equation with slacks

Maximise

$$
\phi_{k}+\varepsilon \sum_{r=1}^{s} s_{r}+\varepsilon \sum_{i=1}^{S} s_{i}
$$

Subject to

$$
\begin{gathered}
\phi_{k} y_{r k}-\sum_{j=1}^{n} \lambda_{j} y_{r j}+s_{r}=0 r=1, \ldots \ldots, s \\
x_{i k}-\sum_{j=1}^{n} \lambda_{j} x_{i j}-s_{i}=0 i=1, \ldots \ldots, m \\
\sum_{j=1}^{n} \lambda_{j}=1 \\
\lambda_{j}, s_{r}, s_{i} \geq 0 \quad \forall_{j}=1, \ldots \ldots, n
\end{gathered}
$$

The results of this research describe two models for comparison. The CCR model takes constant returns to scale into consideration and offers overall technical efficiency results. The BCC model, conversely, divides pure technical efficiency and scale efficiency, taking into consideration variable returns to scale. Efficiency, in that case, can be written as $\mathrm{TE}_{\mathrm{crs}}=\mathrm{TE}_{\mathrm{vrs}} \times \mathrm{SE}$ (Coelli, Rao, O'Donnell, \& Battese, 2005). To summarise, a difference between overall and pure technical efficiency suggests that the port has a scale efficiency and is subsequently rated as inefficient. If BCC overall technical efficiency and CCR pure technical efficiency obtain the same result, scale efficiency also shows the value of 1 . This indicates that the mentioned ports are efficient and do not need to improve their operations, and that they are in the stage of constant returns to scale. If the port is not fully efficient and records scores below the value of 1, the port can be on increasing (irs) or decreasing returns to scale (drs). Those ports that are not fully efficient in 2018 are on increasing returns to scale, although this was not always the case in previous years. In addition, the nonincreasing returns to scale measure can be described T.Eff ${ }_{\mathrm{CRS}}=\mathrm{T}$.Eff NIRS $_{\text {T T.Eff }}$ VRS, in which case irs will prevail, or if T.Eff ${ }_{\text {CRS }}<$ T.Eff $_{\text {NIRS }}=$ T.Eff $_{\mathrm{VRS}}$ then $d r s$ will prevail (Gutiérrez, Lozano, Adenso-Díaz, \& González-Torre, 2015).

\section{Results}

The average CCR overall technical efficiency for the year 2018 obtained the value of 0.54 , which, in theory, indicates that ports could manage to reach the point of efficiency, according to the output-oriented model that is implied in the research, while raising their output level by 1.8 times and keeping the same level of input. In 2009, the average CCR overall efficiency was higher, obtaining the value of 0.57 , which, with all factors unchanged, would imply that ports could achieve efficiency if they increase output by 1.7 times. In $2018,24 \%$ of efficient ports obtained a value of 1 and were placed on the frontier line. This result implies that these ports are allocating resources in the right way and that there is no need for improvement, considering the taken inputs and outputs. Conversely, inefficiency can be due to a range of reasons. As Cullinane and Wang (2006) state, this can include port governance structure, private sector participation, the economic situation in the region, port competition, and 
many other factors that make it challenging to provide a general conclusion about the roots of inefficiency. The second implied model, BCC DEA, divides pure technical efficiency and scale efficiency by displaying results with more information about inefficient DMUs (ports). As shown in Table 1, in 2018, the ports of Catania, Rijeka, and Piombino measure technical efficiency of a value of 1 , but they are not full in terms of overall technical efficiency because their scale efficiency result is lower. This implicates that these ports are not efficient and also indicate that this inefficiency is due to scale factors, as opposed to the disposition of inputs and outputs. Conversely, the majority of ports, both from the 2009 and 2018 results, reveal ports with scale efficiency of value 1 but with pure technical efficiency that is lower than 1. In 2018, eight ports (Ancona, Bari, F. Marittima, Monfalcone, Ortona, Ploce, Salerno, and Savona) and in 200912 ports (Ancona, Bari, Catania, F. Marittima, M. di Carra, Monfalcone, Napoli, Ortona, Ploce, Salerno, Split, and Trieste) exhibited full-scale efficiency and lower pure technical efficiency results. These ports should consider the different allocation of inputs that consider the output, rather than working on scale factors.

To present results, we took two years, 2009 (Table 1), from the beginning of the observed period, and 2018 (Table 2), from the end of the observed period. In 2018, six ports had overall technical efficiency: Genova,

Table 1. Efficiency results for the year 2008

\begin{tabular}{|c|c|c|c|c|c|c|}
\hline Year & Port & Throughput & CCR Overall TE & BCC Pure TE & Scale Eff & Returns to scale \\
\hline 2009 & Ancona & 5074 & 0.199002 & 0.199002 & 1 & - \\
\hline 2009 & Bari & 2345 & 0.173073 & 0.173073 & 1 & - \\
\hline 2009 & Catania & 1283 & 0.231421 & 0.231421 & 1 & - \\
\hline 2009 & Civitavecchia & 4366 & 0.194521 & 0.19688 & 0.98802 & irs \\
\hline 2009 & F. Marittima & 5138 & 0.201512 & 0.201512 & 1 & - \\
\hline 2009 & Genova & 42708 & 1 & 1 & 1 & - \\
\hline 2009 & Koper & 13322 & 1 & 1 & 1 & - \\
\hline 2009 & Livorno & 22176 & 1 & 1 & 1 & - \\
\hline 2009 & M. di Carrara & 2324 & 0.195805 & 0.195805 & 1 & - \\
\hline 2009 & Monfalcone & 5045 & 0.341097 & 0.341097 & 1 & - \\
\hline 2009 & Napoli & 10519 & 0.369375 & 0.369375 & 1 & - \\
\hline 2009 & Omisalj & 5970 & 1 & 1 & 1 & - \\
\hline 2009 & Oristano & 1364 & 0.060747 & 0.061508 & 0.987632 & irs \\
\hline 2009 & Ortona & 1008 & 0.068182 & 0.068182 & 1 & - \\
\hline 2009 & Palermo & 5924 & 0.252436 & 0.267136 & 0.944973 & irs \\
\hline 2009 & Piombino & 8383 & 1 & 1 & 1 & - \\
\hline 2009 & Ploce & 2750 & 0.559832 & 0.559832 & 1 & - \\
\hline 2009 & Ravenna & 23848 & 1 & 1 & 1 & - \\
\hline 2009 & Rijeka & 5962 & 1 & 1 & 1 & - \\
\hline 2009 & Salerno & 4812 & 0.325487 & 0.325487 & 1 & - \\
\hline 2009 & Savona & 15709 & 0.684158 & 0.702837 & 0.973424 & irs \\
\hline 2009 & Split & 2211 & 0.451495 & 0.451495 & 1 & - \\
\hline 2009 & Taranto & 38079 & 1 & 1 & 1 & - \\
\hline 2009 & Trieste & 40986 & 0.95968 & 0.95968 & 1 & - \\
\hline 2009 & Venezia & 26640 & 1 & 1 & 1 & - \\
\hline
\end{tabular}


Table 2. Efficiency results for the year 2018

\begin{tabular}{|c|c|c|c|c|c|c|}
\hline Year & Port & Throughput & CCR Overall TE & BCC Pure TE & Scale Eff & Returns to scale \\
\hline 2018 & Ancona & 5899 & 0.182745 & 0.182745 & 1 & - \\
\hline 2018 & Bari & 5339 & 0.326352 & 0.326352 & 1 & - \\
\hline 2018 & Catania & 6156 & 0.810507 & 1 & 0.810507 & irs \\
\hline 2018 & Civitavecchia & 10561 & 0.344208 & 0.347619 & 0.990189 & irs \\
\hline 2018 & F. Marittima & 4913 & 0.1522 & 0.1522 & 1 & - \\
\hline 2018 & Genova & 51556 & 1 & 1 & 1 & - \\
\hline 2018 & Koper & 23127 & 1 & 1 & 1 & - \\
\hline 2018 & Livorno & 30381 & 1 & 1 & 1 & - \\
\hline 2018 & M. di Carrara & 2218 & 0.170348 & 0.178225 & 0.9558 & irs \\
\hline 2018 & Monfalcone & 4884 & 0.273508 & 0.273508 & 1 & - \\
\hline 2018 & Napoli & 15547 & 0.449289 & 0.450812 & 0.996621 & irs \\
\hline 2018 & Omisalj & 8405 & 1 & 1 & 1 & - \\
\hline 2018 & Oristano & 2073 & 0.067564 & 0.068233 & 0.990189 & irs \\
\hline 2018 & Ortona & 1214 & 0.059939 & 0.059939 & 1 & - \\
\hline 2018 & Palermo & 9672 & 0.300571 & 0.318357 & 0.944133 & irs \\
\hline 2018 & Piombino & 3480 & 0.742423 & 1 & 0.742423 & irs \\
\hline 2018 & Ploce & 3341 & 0.47852 & 0.47852 & 1 & - \\
\hline 2018 & Ravenna & 31058 & 1 & 1 & 1 & - \\
\hline 2018 & Rijeka & 6113 & 0.885959 & 1 & 0.885959 & irs \\
\hline 2018 & Salerno & 7797 & 0.384961 & 0.384961 & 1 & - \\
\hline 2018 & Savona & 13784 & 0.482734 & 0.482734 & 1 & - \\
\hline 2018 & Split & 2099 & 0.294764 & 0.294837 & 0.999751 & irs \\
\hline 2018 & Taranto & 20335 & 0.426885 & 0.433388 & 0.984995 & irs \\
\hline 2018 & Trieste & 57495 & 1 & 1 & 1 & - \\
\hline 2018 & Venezia & 26326 & 0.831611 & 0.833647 & 0.997559 & irs \\
\hline
\end{tabular}

Koper, Livorno, Omisalj, Ravenna, and Trieste. This nuance suggests that their technical and scale efficiency obtain the same result. Also, this result indicates that ports are in the stage of constant returns to scale, and are forming a frontier line as the most efficient DMUs. As previously mentioned, there is no need for their resource allocation, as long as they are operating with the given inputs and outputs. We cannot find a pattern, in terms of port size, as some are the biggest ports in the research but others, like the Slovenian Koper or Croatian Omisalj port, are not particularly big, in terms of annual throughput. In 2009, overall efficiency was measured in nine ports, which means that important ports like Venezia and Taranto became inefficient over time.

Average scale efficiency for 2018 was $97 \%$, which means that scale inefficient ports could reduce their size by $3 \%$, including the current level of inputs and outputs, to reach the optimal size.

Ports on the increasing returns to scale, like Napoli, Rijeka, or ten other ports in 2018, indicate that their throughput would increase, so they should increase their size to achieve optimal scale. In total, 56\% ports were on constant returns to scale in 2018 and $44 \%$ were on the stage of increasing returns to scale. This marks a difference from 2009 , when only $16 \%$ of ports were in the stage of increasing returns to scale and $84 \%$ of ports were showing the result of constant returns to scale.

The results described below, and presented in Figure 1, illustrate how the ports of Genova and Livorno are referent ports to most of the other DMUs. These two ports have an overall efficiency value of 1 , obtained high-performance results, and are placed on the frontier line. Reference data, described below, suggests that these ports represent the best example for other ports with similar inputs and output. Figure 1 presents the defining part of the results delivered by stage two of the DEA output-oriented model that is used in the research, which specifies all efficiency slacks. Two-stage DEA provides results of optimal solutions for the efficiency score (theta). From this, we can observe that the best results are achieved by the ports of Catania, Genova, Koper, and Livorno. 
options: RTS(VRS) ORT(OUT) STAGE(2)

VRS-OUTPUT Oriented DEA Efficiency Results:

\begin{tabular}{|c|c|c|c|c|c|}
\hline & rank & theta & $\begin{array}{c}\text { ref: } \\
\text { Ancona }\end{array}$ & $\begin{array}{l}\text { ref: } \\
\text { Augusta }\end{array}$ & $\begin{array}{l}\text { ref: } \\
\text { Bari }\end{array}$ \\
\hline dmu: Ancona & 22 & .182745 & . & . & . \\
\hline dmu:Bari & 18 & .326352 & . & . & . \\
\hline dmu:Catania & 10 & 1 & . & . & . \\
\hline dmu:Civitavecchia & 17 & .347619 & . & . & . \\
\hline dmu:Falconara_Marittima & 24 & .1522 & . & . & . \\
\hline$\overline{\mathrm{d}} \mathrm{mu}:$ Genova & 7 & 1 & . & . & . \\
\hline dmu:Koper & 2 & 1 & . & . & . \\
\hline \multirow[t]{3}{*}{ dmu: Livorno } & 2 & 1 & . & . & . \\
\hline & ref: & ref: & ref: & ref: & ref: \\
\hline & Catania & Civitavecchia & Falconara_Marittima & Genova & Koper \\
\hline dmu: Ancona & . & . & . & .0442875 & . \\
\hline dmu:Bari & . & . & . & .0410903 & . \\
\hline dmu:Catania & . & . & . & . & . \\
\hline dmu:Civitavecchia & . & . & . & . & . \\
\hline dmu:Falconara_Marittima & . & . & . & .0368849 & . \\
\hline$\overline{d m u}$ : Genova & . & . & . & 1 & . \\
\hline dmu:Koper & . & . & . & . & 1 \\
\hline \multirow[t]{3}{*}{ dmu: Livorno } & . & . & . & 0 & . \\
\hline & ref: & ref: & ref: & ref: & ref: \\
\hline & Livorno & Marina_di_Carrara & Monfalcone & Napoli & Omisalj \\
\hline dmu:Ancona & .106001 & . & . & . & . \\
\hline dmu:Bari & .106005 & . & . & . & $1.40 e-08$ \\
\hline dmu:Catania & .0681181 & . & . & . & .486199 \\
\hline dmu:Civitavecchia & .347619 & . & . & . & $1.39 e-08$ \\
\hline dmu:Falconara_Marittima & .0882829 & . & . & . & . \\
\hline$\overline{\mathrm{d}} \mathrm{mu}:$ Genova & 0 & . & . & . & . \\
\hline dmu:Koper & . & . & . & . & 0 \\
\hline \multirow[t]{2}{*}{ dmu: Livorno } & 1 & . & . & . & . \\
\hline & ref: & $\begin{array}{l}\text { ref: } \\
\text { Trieste }\end{array}$ & ref: & islack: & $\begin{array}{c}\text { islack: } \\
\text { anchoragedeptm }\end{array}$ \\
\hline dmu: Ancona & Tat anto. & .0068755 & . & channelaeptm & $\begin{array}{r}\text { anchoragedeptm } \\
.133976\end{array}$ \\
\hline dmu:Bari & . & . & . & 1.90454 & 1.93966 \\
\hline dmu:Catania & . & 0 & . & . & 9.20435 \\
\hline dmu:Civitavecchia & . & 0 & . & .347618 & 4.86666 \\
\hline dmu:Falconara_Marittima & . & .0057264 & . & . & .111582 \\
\hline$\overline{\mathrm{d} m u}:$ Genova & . & 0 & . & 0 & . \\
\hline dmu:Koper & . & 0 & . & . & 0 \\
\hline \multirow[t]{3}{*}{ dmu: Livorno } & . & 0 & . & . & 0 \\
\hline & islack: & islack: & islack: & islack: & oslack: \\
\hline & closestairportkm & raiway & totalstoragem 2 & imp & $\mathrm{y}$ \\
\hline dmu: Ancona & $8.81 e-07$ & .131582 & . & $1.30 e+07$ & . \\
\hline dmu:Bari & . & .285262 & . & $9.11 e+07$ & . \\
\hline dmu:Catania & .234244 & . & 13939.5 & $4.60 \mathrm{e}+08$ & . \\
\hline dmu:Civitavecchia & 10.4286 & . & 2780.95 & 6.66373 & . \\
\hline dmu:Falconara_Marittima & 0 & .109589 & . & $1.08 \mathrm{e}+07$ & . \\
\hline$\overline{\mathrm{d} m u}$ : Genova & 0 & . & 0 & $2.38 \mathrm{e}-07$ & . \\
\hline dmu: Koper & 0 & 0 & . & 0 & . \\
\hline dmu: Livorno & 0 & 0 & . & 0 & . \\
\hline
\end{tabular}

Figure 1. Selected 'Stage 2' results for the year 2018

The slack results indicate that performance can be improved by subtracting some units from the input and output variables. In our research, that would maximise the output for a given input. Since it is not appropriate for ports to decrease the dept of the channels or anchorage spaces, they should instead accept bigger vessels, as this would result in more throughput and thus maximise output or utilise storage capacity in a better way, in order to influence the output.

\section{Conclusion}

The research here presented indicates different types of efficiency and clearly illustrates to what extent the examined 25 Italian, Croatian, and Slovenian ports are efficient or inefficient. For the year 2018, six ports were fully efficient in all categories and their efficiency was not associated with the size of the port's throughput or location (country). Secondly, the research allows closer analysis of inefficiencies. There are two types of technical efficiency results, crs technical efficiency and vrs technical efficiency, which allow us to separate pure technical efficiency from scale efficiency for all ports that are not fully efficient. For ports like Venezia and Rijeka, which are noted possible destinations for the OBOR Twenty-First Century Maritime Silk Road, it is possible to analyse their technical inefficiency. The Rijeka port's inefficiency is based on the scale factor that, in theory, would mean that the port could reach an efficiency level by decreasing its size. Thirdly, in addition to the general efficiency results, the data demonstrates the ways in which inefficient ports can, by influencing specific inputs, maximise the output and achieve the desired result in performance. The results obtained from the panel data for the mentioned ports of Croatia, Slovenia, and Italy, over the ten-year period, have varied significantly over the years, mainly because of 
the economic crisis that occupied Europe at the beginning of the dataset. In general, scale efficiency suggests higher results than technical efficiency. Such results are common in efficiency measurements. Observation of DEA analysis usually gives the impression that the unit (port) is easily able to reach an efficient point on the frontier line, which is the mathematical feasibility. However, this does not guarantee managerial feasibility in the period of planning. If decision-makers do not accurately determine the effects of managing inputs and outputs, they are at risk of making a mistake (Yang, Wang, \& Li, 2018). The implementation of decisions should be accompanied by an analysis of efficient ports and their operations.

Further research should focus on the impact of private ownership in ports and different types of structural management. Accordingly, it is possible to analyse to what extent these factors have an impact on (in)efficiency, besides port size or infrastructural features. Additionally, the research could be conducted that anticipates the consequences of OBOR's future investments on ports and how this might affect given technical inputs and throughput of ports.

\section{References}

Banker, R. D., Charnes, A., \& Cooper, W. W. (1984). Some Models for Estimating Technical and Scale Inefficiencies in Data Envelopment Analysis. Management Science, 30. https://doi.org/10.1287/mnsc.30.9.1078

Baran, J., \& Gorecka, A. (2015). Seaport efficiency and productivity based on Data Envelopment Analysis and Malmquist Productivity Index. Logistics \& Sustainable Transport, 6, 25-33. https://doi.org/10.1515/jlst-2015-0008

Buljan Perusic, N., \& Zhang, J. H. (2019). Import effect on technical efficiency of cargo ports: Evidence from Italy, Slovenia, and Croatia. Journal of Economics and Sustainable Development, 10, 152-159. https://doi.org/10.7176/JESD/10-22-16

Chang, Y. T. (2013). Environmental efficiency of ports: a Data Envelopment Analysis approach. Maritime Policy \& Management, 40, 467-478. https://doi.org/10.1080/03088839.2013.797119

Charnes, A., Cooper, W., \& Rhodes, E. (1978). Measuring the efficiency of decision making units. European Journal of Operational Research, 429-444. https://doi.org/10.1016/0377-2217(78)90138-8

Clark, X., Dollar, D., \& Micco, A. (2004). Port efficiency, maritime transport costs, and bilateral trade. Journal of Development Economics, 75, 417-450. https://doi.org/10.1016/j.jdeveco.2004.06.005

Coelli, T. J., Rao, D. S., O'Donnell, C. J., \& Battese, G. E. (2005). An Introduction to Efficiency and Productivity Analysis. New York: Springer. https://doi.org/10.1007/b136381

Cooper, W. W., Seiford, L. M., \& Tone, K. (2006). Introduction to Data Envelopment Analysis and Its Uses: With DEA Solver software and References. New York, USA: Springer Science + Business Media, Inc. https://doi.org/10.1007/0-387-29122-9

Cullinane, K. P., \& Wang, T. F. (2006). The efficiency of European container ports: A cross-sectional data envelopment analysis. International Journal of Logistics: Research and Applications, 9, 19-31. https://doi.org/10.1080/13675560500322417

Cullinane, K., Ji, P., \& Wang, T. F. (2005). The relationship between privatization and DEA estimates of efficiency in the container port industry. Journal of Economics and Business, 57, 433-462. https://doi.org/10.1016/j.jeconbus.2005.02.007

Cullinane, K., Song, D. W., Ji, P., \& Wang, T. F. (2004). An Application of DEA Windows Analysis to Container Port Production Efficiency. Review of Network Economics, 3, 184-206. https://doi.org/10.2202/1446-9022.1050

D. Cook, W., Tone, K., \& Zhu, J. (2014). Data envelopment analysis: Prior to choosing a model. Omega, 44, 1-4. https://doi.org/10.1016/j.omega.2013.09.004

Fardella, E., \& Prodi, G. (2017). The Belt and Road Initiative Impact on Europe: An Italian Perspective. China \& World Economy, 25(5), 125-138. https://doi.org/10.1111/cwe.12217

Farrell, M. J. (1957). The measurement of productive efficiency. Journal of the Royal Statistical Society, 120, 253-290. https://doi.org/10.2307/2343100

Gutiérrez, E., Lozano, S., Adenso-Díaz, B., \& González-Torre, P. (2015). Efficiency assessment of container operations of shipping agents in Spanish ports. Maritime Policy \& Management: The Flagship Journal of International Shipping and Port Research, 42, 591-607. https://doi.org/10.1080/03088839.2014.990408 
Huguenin, J. M. (2012). Data Envelopment Analysis (DEA) A pedagogical guide for decision makers in the public sector. Lausanne : IDHEAP - Cahier 276.

Ji, Y. B., \& Lee, C. (2010). Data envelopment analysis. Stata Journal, 10, 267-280.

Kalgora, B., Goli, S. Y., Damigou, B., Abdoulkarim, H. T., \& Amponsem, K. K. (2019). Measuring West-Africa Ports Efficiency Using Data Envelopment Analysis . Journal of Transportation Technologies, 9, 287-308. https://doi.org/10.4236/jtts.2019.93018

Kammoun, R. (2018). The Technical Efficiency of Tunisian Ports:Comparing Data Envelopment Analysis and Stochastic Frontier Analysis Scores. Logistics \& Sustainable Transport, 9, 73-84. https://doi.org/10.2478/j1st-2018-0011

Liu, Q. (2010). Efficiency Analysis of Container Ports and Terminals. Centre for Transport Studies Department of Civil, Environmental and Geomatic Engineering University College London .

Putten, F. P. V., Seaman, J., Huotari, M., Ekman, A., \& Otero-Iglesias, M. (2016). Europe and China's New Silk Roads. ETNC Report.

Roll, Y., \& Hayuth, Y. (1993). Port performance comparison applying data envelopment analysis (DEA). Maritime Policy \& Management: The Flagship Journal of International Shipping and Port Research, 20, 153-161. https://doi.org/10.1080/03088839300000025

Sárvári, B., \& Szeidovitz, A. (2016). The Political Economics of the New Silk Road. Baltic Journal of European Studies, 6(1). https://doi.org/10.1515/bjes-2016-0001

Togzon, J. (2001). Efficiency measurement of selected Australian and other international ports using data envelopment analysis. Transportation Research Part A, 35, 107-122. https://doi.org/10.1016/S0965-8564(99)00049-X

Toloo, M., \& Nalchigar, S. (2009). A new integrated DEA model for finding most BCC-efficient DMU. Applied Mathematical Modelling, 33, 597-604. https://doi.org/10.1016/j.apm.2008.02.001

Valentine, V. F., \& Gray, R. (2001). The Measurement of Port Efficiency Using Data Envelopment Analysis. Proceedings of the 9th World Conference on Transport Research, (pp. 22-27). Seoul, South Korea.

Wilmsmeier, G., \& Spengler, T. (2016). Energy consumption and container terminal efficiency. Bulletin FAL No. 350.

Yang, T., Wang, P., \& Li, F. (2018). Centralized Resource Allocation and Target Setting Based on Data Envelopment Analysis Model. Hindawi Mathematical Problems in Engineering, 1-10. https://doi.org/10.1155/2018/3826096

\section{Copyrights}

Copyright for this article is retained by the author(s), with first publication rights granted to the journal.

This is an open-access article distributed under the terms and conditions of the Creative Commons Attribution license (http://creativecommons.org/licenses/by/4.0/). 